\title{
Who Favors Education? Insights from the World Values Survey
}

\author{
Horst Feldmann \\ Department of Economics, University of Bath, Bath, UK \\ h.feldmann@bath.ac.uk
}

\begin{abstract}
Using World Values Survey data from 55 countries, this article provides detailed insights into the characteristics of people who place a high value on education - and into the characteristics of those who don't. It finds that attitudes toward education vary across the following characteristics: educational attainment, income, social class, political position, postmaterialist values, religion, sex, age, ethnicity, marital status, number of children, family values and employment status. Countries' average GDP per capita affects people's views of education too. Whereas some results are in line with theoretical expectations and previous empirical research, others are surprising.
\end{abstract}

\section{Keywords}

education - schooling - values

\section{Introduction}

Social scientists have long recognized that education is beneficial to both the individual and society (e.g., Durkheim 1956, Schultz 1963, Becker 1993 [1964]). However, in order to realize these benefits it is important that people appreciate education. Indeed, many empirical studies indicate that parents' and students' views of education are of crucial importance for both the quantity and quality of educational investment. For example, several studies document a strong relation between parents' educational beliefs and achievement outcomes (e.g., Alexander et al. 1994, Hoover-Dempsey and Sandler 1997). Furthermore, in developed countries such as the United States and the United Kingdom parents 
are willing to pay more for houses that are located closer to better schools (e.g., Black 1999), indicating that they place a high value on good education. This in turn may put pressure on educational providers to improve school quality.

In developing countries, even many very poor parents send their children to fee-charging private schools, in the light of the frequently poor quality of state schools, although these normally do not charge fees (e.g., Tooley 2013). Indeed, there is strong evidence that in many developing countries both teaching and learning outcomes are better in private schools than in state schools (e.g., Day Ashley et al. 2014). Consequently, in numerous developing countries private schooling has grown strongly in recent decades (e.g., Gandhi Kingdon 2017, Elacqua et al. 2018). Thus, in developing countries, too, most parents do not only have a high regard for education in the abstract, it also largely shapes their demand for schooling. This favorably affects both the quantity and the quality of education children receive.

Other research finds that not only parents' but also students' attitudes toward education are important. Specifically, students' beliefs about learning contribute to their motivation to learn, the number of years spent in education and their academic achievements (e.g., Strand 2007, Croll et al. 2008, Khamis et al. 2008).

An example of the importance of a positive view of education is provided by Confucian heritage societies - i.e., countries such as China, Japan, South Korea and Vietnam. In these societies, education has been held in high regard for centuries (Yang 1993, Lee 2000). Today people still attach great importance to education, irrespective of social class or gender. They see education both as the most promising way for character development and as a pathway to upward social mobility (To 1993, Starr 2012). They believe that anyone can succeed with effort. Building on this traditional attitude, East Asian governments in recent decades have made education a key element of their development strategies, investing heavily in this area (World Bank 1993). This is complemented by substantial out-of-school tuition and a strong work ethic. As a result, for many years Confucian heritage societies have been outperforming most other countries and societies in international tests of student performance (e.g., OECD 2015). As a further result of their high regard for education, these countries have achieved some of the highest rates of economic growth over the past decades (Hanushek and Woessmann 2016), not only lifting millions of people out of poverty but also enabling most of them to join an ever more prosperous middle class.

As the East Asian example illustrates, the success of educational initiatives by governments depends on people's attitudes toward education. In developing countries, this is also true for educational initiatives by foreign donors public and private - as well as the United Nations. For example, achieving the 
education goal of the UN's "203o Agenda for Sustainable Development” (United Nations 2015) depends on people in these countries attaching great importance to education.

Although it is of key importance for the amount and quality of educational investment undertaken that people have a high regard for education, few social scientists have studied which people actually do (e.g., Cook and Ludwig 1997, Gorman 1998, Francis and Archer 2005, Weir 2011, Kooij and Zacher 2016). Who favors education - and who doesn't? The previous literature makes important contributions. However, it is limited in scope. Almost all of these papers use data from a single country only, with nationally unrepresentative samples. By contrast, our article covers 55 countries from all over the world, both developed and developing countries (for a list of countries, see Appendix). The data we use are from the World Values Surveys, which are nationally representative (Inglehart et al. 2015). These surveys collect extensive information both about participants' characteristics and their values and beliefs, enabling us to study our research question in detail. This is another improvement on previous papers, each of which looks at a few such characteristics only.

The remainder of our article proceeds in the following way. Section 2 explains our data and methodology. It also provides a brief overview over the related literature. Section 3 presents and discusses our regression results. Section 4 concludes.

\section{Data and Methodology}

\subsection{Dependent Variables}

To capture different dimensions of people's attitudes toward education, we use four different dummy variables (for definitions and descriptive statistics of all variables, see Table 1). The first equals one if a respondent selected as their first choice "inadequate education" as the most serious problem of the world. The alternatives were: "people living in poverty and need", "discrimination against girls and women", "poor sanitation and infectious diseases" and "environmental pollution".

Our second dependent variable is phrased in the same way as the first, except that it focusses on the respondent's own country, rather than the world. Thus, this variable equals one if a respondent selected as their first choice "inadequate education" as the most serious problem for their own country. The alternative answer categories were the same as for the first question used.

A major plus of these questions is that they require respondents to make trade-offs, as is the case with all real choices. In surveys that do not require this, virtually all respondents - parents and students alike - normally acknowledge 
the importance of education (e.g., Croll et al. 2008, Spera et al. 2009). In such surveys, they may feel compelled to give socially desirable responses, especially in societies that have traditionally held education in high regard (Jacob and Lefgren 2007).

Our third dependent variable equals one if a respondent said that they worried very much or a great deal about "not being able to give my children a good education". It equals zero if they said that they worried about this not much or not at all. Hence, whereas the first variable measures the value respondents put on education more generally, the third focusses on the value they put on the education of their children. The second variable is located between these polar cases: it has a general dimension because it does not refer to the respondent's children, but also a personal dimension insofar as it refers to their own country. Hence, as we move from the first to the second and then to the third variable, we gradually move from a general to a personal perspective.

Interestingly, the most personal question has by far the highest share of respondents agreeing with it: no less than $71 \%$ were worried about their children's education. By contrast, only $10 \%$ and $12 \%$, respectively, selected inadequate education as the most serious problem of the world or their own country.

Note that the answers to questions 2 and 3 do not exclusively reflect the value respondents placed on education. They also reflect the quality of the national school systems and, as far as question 3 is concerned, income levels. Fortunately, we are able to control for these confounding influences at least to some degree. We do so in two ways. First, we use country dummies, which capture the time-invariant dimension of both the quality of national school systems and the level of national economic development. Second, we include among our explanatory variables 'income' and, in our main robustness check, 'GDP per capita' (section 2.2).

Our fourth dependent variable measures yet another dimension of people's attitudes toward education: gender equality. It takes the value one if a respondent agreed or strongly agreed with the statement that going to university is more important for a boy than for a girl. $21 \%$ of respondents did. Like our first dependent variable, this variable measures people's attitudes in a more general sense because it does not explicitly take respondents' personal or national circumstances into account.

The World Values Survey included questions 1 and 4 in both wave 5 (2005o9) and wave 6 (2010-14). ${ }^{1}$ By contrast, question 2 was included in wave 5 only and question 3 only in wave 6 . Also, these two questions were asked in far

1 Question 4 was also included in waves 3 (1995-98) and 4 (1999-2004). However, we refrain from using these earlier data. To maximize comparability of results, we aim to have a sample 
fewer than 55 countries. Therefore, the number of observations in the regressions using these two dependent variables is considerably lower than in the other regressions (Tables 2 and 3 ).

Variable

Definition

Mean Std. dev. Min. Max.

\begin{tabular}{|c|c|c|c|c|c|}
\hline $\begin{array}{l}\text { Inadequate } \\
\text { education most } \\
\text { serious problem } \\
\text { of the world }\end{array}$ & $\begin{array}{l}\text { Dummy variable that equals } 1 \text { if } \\
\text { respondent selected as his first choice } \\
\text { "inadequate education" as the most serious } \\
\text { problem of the world. Other answer } \\
\text { categories: "People living in poverty and } \\
\text { need", "Discrimination against girls and } \\
\text { women", "Poor sanitation and infectious } \\
\text { diseases" and "Environmental pollution". }\end{array}$ & 0.10 & 0.30 & o & 1 \\
\hline $\begin{array}{l}\text { Inadequate } \\
\text { education most } \\
\text { serious problem } \\
\text { for their own } \\
\text { country }\end{array}$ & $\begin{array}{l}\text { Dummy variable that equals } 1 \text { if } \\
\text { respondent selected as his first choice } \\
\text { "inadequate education" as the most serious } \\
\text { problem for his own country. Other answer } \\
\text { categories: "People living in poverty and } \\
\text { need", "Discrimination against girls and } \\
\text { women", "Poor sanitation and infectious } \\
\text { diseases" and "Environmental pollution". }\end{array}$ & 0.12 & 0.32 & o & 1 \\
\hline $\begin{array}{l}\text { Worried about } \\
\text { not being able } \\
\text { to give their } \\
\text { children a good } \\
\text { education }\end{array}$ & $\begin{array}{l}\text { Dummy variable that equals } 1 \text { if } \\
\text { respondent said that he worried very much } \\
\text { or a great deal about "not being able to give } \\
\text { my children a good education". It equals } \\
\text { o if he said that he worried about this not } \\
\text { much or not at all. }\end{array}$ & 0.71 & 0.45 & o & 1 \\
\hline $\begin{array}{l}\text { University more } \\
\text { important for } \\
\text { a boy than for } \\
\text { a girl }\end{array}$ & $\begin{array}{l}\text { Dummy variable that equals } 1 \text { if } \\
\text { respondent agreed or strongly agreed with } \\
\text { the following statement: "University is } \\
\text { more important for a boy than for a girl". }\end{array}$ & 0.21 & 0.40 & o & 1 \\
\hline
\end{tabular}

period as similar as possible across our regressions. For example, attitudes toward female university education generally were more conservative in earlier years. 
Educational attainment (excluded category: inadequately completed elementary education)

\begin{tabular}{|c|c|c|c|c|}
\hline $\begin{array}{l}\text { Elementary } \\
\text { education }\end{array}$ & $\begin{array}{l}\text { Dummy variable that equals } 1 \text { if } \\
\text { respondent's highest educational level } \\
\text { attained was "Completed (compulsory) } \\
\text { elementary education". }\end{array}$ & 0.12 & 0.32 & O \\
\hline $\begin{array}{l}\text { Middle } \\
\text { education }\end{array}$ & $\begin{array}{l}\text { Dummy variable that equals } 1 \text { if } \\
\text { respondent's highest educational level } \\
\text { attained was either "Incomplete secondary } \\
\text { school: technical/vocational type/ } \\
\text { (Compulsory) elementary education and } \\
\text { basic vocational qualification", "Complete } \\
\text { secondary school: technical/vocational } \\
\text { type/Secondary, intermediate vocational } \\
\text { qualification", "Incomplete secondary: } \\
\text { university-preparatory type/Secondary, } \\
\text { intermediate general qualification" } \\
\text { or "Complete secondary: university- } \\
\text { preparatory type/Full secondary, maturity } \\
\text { level certificate". }\end{array}$ & 0.55 & 0.50 & o \\
\hline $\begin{array}{l}\text { Higher } \\
\text { education }\end{array}$ & $\begin{array}{l}\text { Dummy variable that equals } 1 \text { if } \\
\text { respondent's highest educational level } \\
\text { attained was either "Some university } \\
\text { without degree/Higher education - lower- } \\
\text { level tertiary certificate" or "University with } \\
\text { degree/Higher education - upper-level } \\
\text { tertiary certificate". }\end{array}$ & 0.27 & 0.44 & o \\
\hline
\end{tabular}


Variable

\begin{tabular}{|c|c|c|c|c|c|}
\hline Income & $\begin{array}{l}\text { Respondent's positioning of his } \\
\text { household's income on a scale ranging } \\
\text { from } 1 \text { (=lowest income group) to } 11 \\
\text { (=highest income group). The scale refers } \\
\text { to his country. The respondent was asked } \\
\text { to take into account all wages, salaries, } \\
\text { pensions and other incomes of his } \\
\text { household. }\end{array}$ & 5.00 & 2.13 & 1 & 10 \\
\hline \multicolumn{6}{|c|}{ Social class (excluded category: working class) } \\
\hline Middle class & $\begin{array}{l}\text { Dummy variable that equals } 1 \text { if } \\
\text { respondent described himself as belonging } \\
\text { to the middle class. }\end{array}$ & 0.57 & 0.50 & o & 1 \\
\hline Upper class & $\begin{array}{l}\text { Dummy variable that equals } 1 \text { if } \\
\text { respondent described himself as belonging } \\
\text { to the upper class. }\end{array}$ & 0.02 & 0.14 & o & 1 \\
\hline \multicolumn{6}{|c|}{ Political position (excluded category: political center) } \\
\hline Political left & $\begin{array}{l}\text { Dummy variable that equals } 1 \text { if } \\
\text { respondent described his views as } \\
\text { left-wing. }\end{array}$ & 0.16 & 0.36 & o & 1 \\
\hline Political right & $\begin{array}{l}\text { Dummy variable that equals } 1 \text { if } \\
\text { respondent described his views as } \\
\text { right-wing. }\end{array}$ & 0.25 & 0.43 & o & 1 \\
\hline
\end{tabular}


to range from o (materialism $[\mathrm{M}])$ to 1 (postmaterialism [PM]). The index is based on how important respondents think the following 12 items are: (1) Maintaining a high level of economic growth $[\mathrm{M}]$. (2) Making sure this country has strong defense forces [M]. (3) Seeing that people have more to say about how things are done at their jobs and in their communities [PM]. (4) Trying to make our cities and countryside more beautiful [PM].

(5) Maintaining order in the nation [M]. (6) Giving people more say in important government decisions [PM]. (7) Fighting rising prices $[\mathrm{M}]$. (8) Protecting freedom of speech [PM]. (9) A stable economy [M]. (10) Progress toward a less impersonal and more humane society [PM]. (11) Progress toward a society in which ideas count more than money [PM]. (12) The fight against crime $[\mathrm{M}]$.

Religion adherence (excluded category: non-religious)

Protestant Dummy variable that equals 1 if $\begin{array}{llll}0.16 & 0.36 & 0 & 1\end{array}$ respondent adhered to Protestantism.

\begin{tabular}{|c|c|c|c|c|}
\hline $\begin{array}{l}\text { Roman } \\
\text { Catholic }\end{array}$ & $\begin{array}{l}\text { Dummy variable that equals } 1 \text { if } \\
\text { respondent adhered to Roman Catholicism. }\end{array}$ & 0.22 & 0.42 & o \\
\hline $\begin{array}{l}\text { Eastern } \\
\text { Orthodox }\end{array}$ & $\begin{array}{l}\text { Dummy variable that equals } 1 \text { if } \\
\text { respondent adhered to Eastern Orthodoxy. }\end{array}$ & 0.15 & 0.35 & o \\
\hline $\begin{array}{l}\text { Other } \\
\text { Christian }\end{array}$ & $\begin{array}{l}\text { Dummy variable that equals } 1 \text { if } \\
\text { respondent adhered to a Christian } \\
\text { religion other than Roman Catholicism, } \\
\text { Protestantism and Eastern Orthodoxy. }\end{array}$ & 0.02 & 0.13 & o \\
\hline Jewish & $\begin{array}{l}\text { Dummy variable that equals } 1 \text { if } \\
\text { respondent adhered to Judaism. }\end{array}$ & 0.01 & 0.07 & o \\
\hline
\end{tabular}




\begin{tabular}{|c|c|c|c|c|c|}
\hline Muslim & $\begin{array}{l}\text { Dummy variable that equals } 1 \text { if } \\
\text { respondent adhered to Islam. }\end{array}$ & 0.18 & 0.39 & $\mathrm{o}$ & 1 \\
\hline Hindu & $\begin{array}{l}\text { Dummy variable that equals } 1 \text { if } \\
\text { respondent adhered to Hinduism. }\end{array}$ & 0.01 & 0.12 & o & 1 \\
\hline Buddhist & $\begin{array}{l}\text { Dummy variable that equals } 1 \text { if } \\
\text { respondent adhered to Buddhism. }\end{array}$ & 0.05 & 0.22 & o & 1 \\
\hline $\begin{array}{l}\text { Other Eastern } \\
\text { religions }\end{array}$ & $\begin{array}{l}\text { Dummy variable that equals } 1 \text { if } \\
\text { respondent adhered to an Eastern religion } \\
\text { other than Hinduism and Buddhism. }\end{array}$ & 0.00 & 0.06 & o & 1 \\
\hline $\begin{array}{l}\text { Other } \\
\text { religions }\end{array}$ & $\begin{array}{l}\text { Dummy variable that equals } 1 \text { if } \\
\text { respondent adhered to other religions than } \\
\text { Christianity, Judaism, Islam, Hinduism, } \\
\text { Buddhism and other Eastern religions. }\end{array}$ & 0.04 & 0.19 & o & 1 \\
\hline God important & $\begin{array}{l}\text { Respondent's answer to the question, } \\
\text { "How important is God in your life?" } \\
\text { Scale from } 1 \text { (=Not at all important) to } 10 \\
\text { (= Very important). }\end{array}$ & $7 \cdot 72$ & 2.94 & 1 & 10 \\
\hline Female & $\begin{array}{l}\text { Dummy variable that equals } 1 \text { if } \\
\text { respondent was female. }\end{array}$ & 0.50 & $0.5^{\circ}$ & o & 1 \\
\hline Age & Age of respondent in years. & 41.14 & 16.26 & 15 & 97 \\
\hline $\operatorname{Age}^{2}$ & Age of respondent squared. & 1957.13 & 1502.47 & 22594 & 409 \\
\hline \multicolumn{6}{|c|}{ Ethnicity (excluded category: other ethnicity) } \\
\hline White & $\begin{array}{l}\text { Dummy variable that equals } 1 \text { if } \\
\text { respondent's ethnicity was "White". }\end{array}$ & 0.44 & 0.50 & o & 1 \\
\hline Black & $\begin{array}{l}\text { Dummy variable that equals } 1 \text { if } \\
\text { respondent's ethnicity was "Black". }\end{array}$ & 0.17 & 0.38 & o & 1 \\
\hline East Asian & $\begin{array}{l}\text { Dummy variable that equals } 1 \text { if } \\
\text { respondent's ethnicity was "East Asian". }\end{array}$ & 0.06 & 0.24 & o & 1 \\
\hline $\begin{array}{l}\text { Other Asian } \\
\text { or Arab }\end{array}$ & $\begin{array}{l}\text { Dummy variable that equals } 1 \text { if } \\
\text { respondent's ethnicity was "Other Asian or } \\
\text { Arab". }\end{array}$ & 0.19 & 0.39 & o & 1 \\
\hline Health & $\begin{array}{l}\text { Respondent's answer to the question, "All } \\
\text { in all, how would you describe your state } \\
\text { of health these days?" Scale: } 1=\text { very poor, } \\
2=\text { poor, } 3=\text { fair, } 4=\text { good, } 5=\text { =ery good. }\end{array}$ & $3 \cdot 93$ & 0.84 & 2 & 5 \\
\hline
\end{tabular}




\begin{tabular}{|c|c|c|c|c|c|}
\hline Variable & Definition & Mean & Std. dev. & Min. & Max. \\
\hline Married & $\begin{array}{l}\text { Dummy variable that equals } 1 \text { if } \\
\text { respondent was married. }\end{array}$ & $0.5^{2}$ & $0.5^{\circ}$ & o & \\
\hline $\begin{array}{l}\text { Living } \\
\text { together }\end{array}$ & $\begin{array}{l}\text { Dummy variable that equals } 1 \text { if } \\
\text { respondent lived together as married. }\end{array}$ & 0.09 & 0.28 & $\mathrm{O}$ & \\
\hline Divorced & $\begin{array}{l}\text { Dummy variable that equals } 1 \text { if } \\
\text { respondent was divorced. }\end{array}$ & 0.04 & 0.20 & o & \\
\hline Separated & $\begin{array}{l}\text { Dummy variable that equals } 1 \text { if } \\
\text { respondent was separated. }\end{array}$ & 0.02 & 0.15 & o & \\
\hline Widowed & $\begin{array}{l}\text { Dummy variable that equals } 1 \text { if } \\
\text { respondent was widowed. }\end{array}$ & 0.06 & 0.23 & o & 1 \\
\hline Children & The respondent's number of children. & 1.72 & 1.67 & o & \\
\hline $\begin{array}{l}\text { Family } \\
\text { important }\end{array}$ & $\begin{array}{l}\text { Dummy variable that equals } 1 \text { if } \\
\text { respondent said that family was very } \\
\text { important or rather important in his life. It } \\
\text { equals o if he said that family was not very } \\
\text { important or not at all important. }\end{array}$ & 0.99 & 0.11 & o & 1 \\
\hline \multicolumn{6}{|c|}{ Employment status (excluded category: non-employed) } \\
\hline Employed & $\begin{array}{l}\text { Dummy variable that equals } 1 \text { if } \\
\text { respondent was employed (full time, part } \\
\text { time or self-employed). }\end{array}$ & $0.5^{8}$ & 0.49 & $\mathrm{o}$ & 1 \\
\hline Unemployed & $\begin{array}{l}\text { Dummy variable that equals } 1 \text { if } \\
\text { respondent was unemployed. }\end{array}$ & 0.10 & 0.30 & $\mathrm{O}$ & \\
\hline Town & $\begin{array}{l}\text { Size of town in which respondent lived. } \\
\text { Scale ranging from } 1 \text { (=under } 2,000) \text { to } 8 \\
(=500,000 \text { and more). }\end{array}$ & $4 \cdot 77$ & 2.49 & 1 & \\
\hline GDP per capita & $\begin{array}{l}\text { Real GDP per capita, in tens of thousands } \\
\text { of } 2011 \text { US dollar, at purchasing power } \\
\text { parity. }\end{array}$ & 1.67 & 1.31 & 0.08 & 4.63 \\
\hline
\end{tabular}

Note: The data are from World Values Survey waves 5 (2005-o9) and 6 (2010-14) (Inglehart et al. 2015), except for data on 'GDP per capita', which are from Feenstra et al. (2019). 


\subsection{Explanatory Variables}

In order to study a large number of characteristics of individuals with different views of education, our regressions include numerous explanatory variables. To start with, we use variables measuring respondents' educational attainment. We expect people with higher attainment to attach greater importance to education because they should have experienced its benefits first-hand. Related research has established that children of better educated parents tend to have superior academic achievements, partly because these parents support their children more (e.g., Knight and Li 1996, Rainey and Murova 2004, DavisKean 2005, Njagi et al. 2014). This suggests that better educated parents value education more highly.

Another variable is based on a question about a respondent's household income, relative to income levels in their country. Research on the determinants of educational attainment shows that children from more affluent families tend to have higher attainments than children from low-income families (Haveman and Wolfe 1995, Liu 2003). Hastings et al. (2006) report that preferences for school quality increase with income. These results lead us to expect that members of more affluent households value education more highly as well.

We include two variables capturing respondents' social class because several papers have documented a relationship between social class and educational values (e.g., Kinloch 1987, Gorman 1998). Additionally, we include variables measuring respondents' political position because some papers find educational attitudes to vary across the political spectrum (e.g., Bradley and Saigol 2012, Fladmoe 2012).

Furthermore, we use the World Values Survey's postmaterialist index, which ranges from materialism to postmaterialism. Whereas materialist values give priority to economic and physical security, postmaterialist values emphasize issues such as participation and free speech. Inglehart $(1977,1990,1997)$ has documented that a profound shift toward postmaterialist values has occurred since 1970 in developed countries and that this has transformed their basic cultural norms. He gives the example of gender roles, mentioning that today women are the majority of university students in most developed countries (Inglehart 2018). But he also points out that, in the world as a whole, the ratio between materialists and postmaterialists varies tremendously according to a country's level of economic development.

Next, we include variables that measure adherence to each major world religion, plus variables for adherence to other religions. Each religion has its distinctive educational ideals (Feldmann 2016a). Although education has long been secularized in almost all countries, these ideals are still likely to affect adherents' attitudes toward education. As this is most likely to be the case for 
people who are very religious, we additionally include a variable measuring respondents' religiosity.

Moreover, we use a dummy variable that equals one if a respondent was female. Some, though not all, previous papers report differences between mothers' and fathers' attitudes toward education of their children (e.g., Weir 2011). Using UK data, Cooper (2017) finds that mothers are particularly keen for their daughters to go to university. We also estimate the impact of respondents' age, although results from previous studies on this are mixed (e.g., Fullerton and Dixon 2010, Kooij and Zacher 2016).

Additionally, we estimate the effect of ethnicity. The most clear-cut result in the literature is that East Asians attach great importance to education (e.g., Francis and Archer 2015, Jerrim 2015). As pointed out in section 1, this is due to their Confucian heritage, rather than to their ethnicity as such. Apart from the East Asians, different ethnic groups do not seem to place strongly different degrees of emphasis on education. This at least is the upshot of studies on the United States, the by far best researched country. Though Ryan et al. (2010) find some differences between Hispanics and Whites, Johnson and Kotrlik (2012) do not find any in their sample. Also, there do not seem to be significant differences between Blacks and Whites (e.g., Cook and Ludwig 1997).

We also include a variable measuring respondents' state of health. The effect of health on people's views of education has not yet been studied. Theory suggests and numerous empirical studies confirm that improvements in health have a positive effect on educational investments - mainly because they increase the time horizon over which such investments pay off (e.g., Soares 2005, Alderman et al. 2006, Jayachandran and Lleras-Muney 2009). Yet, it would be far-fetched to expect that healthier respondents have a higher regard for education.

There is also no research yet on how people's educational attitudes are affected by their marital status. However, it seems plausible to expect that education is comparatively important to married couples, even if they do not yet have any children. On the other hand, it is probably less important to singles.

Furthermore, we use both a variable measuring respondents' number of children and a dummy variable recording if family was important in their lives. We expect both variables to have a positive effect on the value respondents place on education. Especially, we expect them to worry more about not being able to give their children a good education if they have many. In line with Becker's quantity-quality trade-off hypothesis (Becker and Lewis 1973, Becker and Tomes 1976), previous empirical research has found a larger family size to adversely affect children's education, especially that of girls (e.g., Hanushek 1992, Kang 2011, Ponczek and Portela Souza 2012). 
Respondents' employment status is also likely to particularly affect their answers to the third question. Employed parents may have little time and energy to invest in their children's education (e.g., Weiss et al. 2003). Unemployed parents may lack the financial resources, skills and connections to do so. Thus both may worry about being able to give their children a good education.

The final explanatory variable used in our baseline model measures the size of the town in which respondents lived. On the one hand, living in a larger town may be correlated with a higher value placed on education because larger towns provide more employment opportunities and usually higher returns to education. On the other hand, Kong (2010) reports that in China rural parents attach particularly great importance to education because they want their children to escape the harsh life that they themselves as farmers with little education had lived.

In our main robustness check, we add a country-level variable: GDP per capita. As returns to education fall by level of economic development (e.g., Psacharopoulos and Patrinos 2018), one could expect people in poorer countries to place a higher value on education. On the other hand, as both school enrollment rates and average years of schooling rise by economic development (e.g., Lee and Lee 2016), this could indicate that the value people place on education is higher in richer countries.

\subsection{Econometric Specification}

Using probit, we estimate the following model:

$$
Y_{j, i, t}=\alpha+\sum_{k=1}^{r} \beta_{k} X_{k, j, i, t}+\gamma Z_{i, t}+\delta_{i}+\theta_{t}+\varepsilon_{j, i, t}
$$

$Y_{j, i, t}$ denotes one of our four variables measuring regard for education by individual $j$ in country $i$ and survey year $t . X_{k, j, i, t}$ denotes a vector of $r$ individuallevel explanatory variables. $Z_{i, t}$ denotes 'GDP per capita', a country-level variable. While $\alpha$ is the constant, $\delta_{i}$ and $\theta_{t}$ denote country and year dummies, respectively. Finally, $\varepsilon_{j, i, t}$ represents the error term.

Country dummies are included to control for the impact of unobserved country-specific characteristics such as geographical conditions. Year dummies are included to control for the impact of shocks that are common across countries. $^{2}$

2 As questions 2 and 3 were included in one wave only, year dummies are omitted from the respective regressions. 
(1) (2)

(3)

(4)

Inadequate Inadequate Worried about University more

education most education most not being able important for

serious problem serious problem to give their a boy than for

of the world for their own children a good a girl country education

\begin{tabular}{|c|c|c|c|c|}
\hline Elementary education & $\begin{array}{c}0.011 \\
(0.008)\end{array}$ & $\begin{array}{l}0.020^{*} \\
(0.010)\end{array}$ & $\begin{array}{c}0.022 \\
(0.022)\end{array}$ & $\begin{array}{l}-0.010 \\
(0.011)\end{array}$ \\
\hline Middle education & $\begin{array}{l}0.024^{* * *} \\
(0.007)\end{array}$ & $\begin{array}{l}0.035^{* *} \\
(0.014)\end{array}$ & $\begin{array}{c}0.018 \\
(0.014)\end{array}$ & $\begin{array}{l}-0.061 * * * \\
(0.010)\end{array}$ \\
\hline Higher education & $\begin{array}{l}0.045^{* * *} \\
(0.010)\end{array}$ & $\begin{array}{l}0.049^{* * *} \\
(0.015)\end{array}$ & $\begin{array}{c}0.004 \\
(0.016)\end{array}$ & $\begin{array}{l}-0.111 * * * \\
(0.012)\end{array}$ \\
\hline Income & $\begin{array}{l}0.002^{* * *} \\
(0.001)\end{array}$ & $\begin{array}{l}0.005^{* * *} \\
(0.001)\end{array}$ & $\begin{array}{l}-0.011 \text { *** } \\
(0.003)\end{array}$ & $\begin{array}{c}0.000 \\
(0.002)\end{array}$ \\
\hline Middle class & $\begin{array}{l}0.013^{* * *} \\
(0.003)\end{array}$ & $\begin{array}{c}0.002 \\
(0.008)\end{array}$ & $\begin{array}{l}-0.010 \\
(0.012)\end{array}$ & $\begin{array}{c}-0.007 \\
(0.005)\end{array}$ \\
\hline Upper class & $\begin{array}{l}0.029^{* * *} \\
(0.006)\end{array}$ & $\begin{array}{c}0.000 \\
(0.016)\end{array}$ & $\begin{array}{l}-0.060^{* * *} \\
(0.020)\end{array}$ & $\begin{array}{l}0.034^{* *} \\
(0.016)\end{array}$ \\
\hline Political left & $\begin{array}{c}-0.005 \\
(0.004)\end{array}$ & $\begin{array}{c}-0.003 \\
(0.010)\end{array}$ & $\begin{array}{l}-0.010 \\
(0.010)\end{array}$ & $\begin{array}{c}-0.005 \\
(0.007)\end{array}$ \\
\hline Political right & $\begin{array}{c}0.001 \\
(0.005)\end{array}$ & $\begin{array}{l}-0.002 \\
(0.012)\end{array}$ & $\begin{array}{c}0.003 \\
(0.012)\end{array}$ & $\begin{array}{l}0.030^{* * *} \\
(0.005)\end{array}$ \\
\hline Postmaterialist & $\begin{array}{l}\text { o.049*** } \\
(0.009)\end{array}$ & $\begin{array}{l}0.049^{* * *} \\
(0.014)\end{array}$ & $\begin{array}{c}-0.015 \\
(0.017)\end{array}$ & $\begin{array}{c}-0.018 \\
(0.018)\end{array}$ \\
\hline Protestant & $\begin{array}{l}-0.011^{* *} \\
(0.005)\end{array}$ & $\begin{array}{c}-0.020^{* *} \\
(0.008)\end{array}$ & $\begin{array}{c}0.007 \\
(0.021)\end{array}$ & $\begin{array}{c}0.012 \\
(0.009)\end{array}$ \\
\hline Roman Catholic & $\begin{array}{c}-0.009 * \\
(0.005)\end{array}$ & $\begin{array}{l}-0.015 \\
(0.010)\end{array}$ & $\begin{array}{c}0.010 \\
(0.020)\end{array}$ & $\begin{array}{c}0.015 \\
(0.009)\end{array}$ \\
\hline Eastern Orthodox & $\begin{array}{l}-0.025^{* *} \\
(0.010)\end{array}$ & $\begin{array}{c}-0.012 \\
(0.018)\end{array}$ & $\begin{array}{c}0.018 \\
(0.020)\end{array}$ & $\begin{array}{l}0.043^{* * *} \\
(0.014)\end{array}$ \\
\hline Other Christian & $\begin{array}{c}-0.024^{*} \\
(0.013)\end{array}$ & $\begin{array}{c}-0.005 \\
(0.016)\end{array}$ & $\begin{array}{l}-0.017 \\
(0.020)\end{array}$ & $\begin{array}{l}-0.033^{* *} \\
(0.013)\end{array}$ \\
\hline Jewish & $\begin{array}{c}0.009 \\
(0.017)\end{array}$ & $\begin{array}{c}0.018 \\
(0.048)\end{array}$ & $\begin{array}{l}0.077^{* *} \\
(0.034)\end{array}$ & $\begin{array}{c}0.063^{*} \\
(0.034)\end{array}$ \\
\hline Muslim & $\begin{array}{c}0.001 \\
(0.013)\end{array}$ & $\begin{array}{l}-0.032^{* *} \\
(0.013)\end{array}$ & $\begin{array}{c}0.041 \\
(0.028)\end{array}$ & $\begin{array}{l}0.056 \text { *** } \\
(0.021)\end{array}$ \\
\hline
\end{tabular}




\begin{tabular}{|c|c|c|c|c|}
\hline & $\begin{array}{l}(1) \\
\text { Inadequate } \\
\text { education most } \\
\text { serious problem } \\
\text { of the world }\end{array}$ & $\begin{array}{l}(2) \\
\text { Inadequate } \\
\text { education most } \\
\text { serious problem } \\
\text { for their own } \\
\text { country }\end{array}$ & $\begin{array}{l}\text { (3) } \\
\text { Worried about } \\
\text { not being able } \\
\text { to give their } \\
\text { children a good } \\
\text { education }\end{array}$ & $\begin{array}{l}\text { (4) } \\
\text { University more } \\
\text { important for } \\
\text { a boy than for } \\
\text { a girl }\end{array}$ \\
\hline Hindu & $\begin{array}{c}-0.006 \\
(0.017)\end{array}$ & $\begin{array}{c}-0.022 \\
(0.019)\end{array}$ & $\begin{array}{c}-0.038 \\
(0.028)\end{array}$ & $\begin{array}{c}0.001 \\
(0.021)\end{array}$ \\
\hline Buddhist & $\begin{array}{c}-0.013 \\
(0.017)\end{array}$ & $\begin{array}{c}0.013 \\
(0.019)\end{array}$ & $\begin{array}{l}-0.001 \\
(0.020)\end{array}$ & $\begin{array}{l}0.080 * * \\
(0.033)\end{array}$ \\
\hline Other Eastern religions & $\begin{array}{l}0.057^{* *} \\
(0.026)\end{array}$ & $\begin{array}{l}-0.015^{* * *} \\
(0.005)\end{array}$ & $\begin{array}{c}0.135 \\
(0.099)\end{array}$ & $\begin{array}{l}0.049^{* * *} \\
(0.010)\end{array}$ \\
\hline Other religions & $\begin{array}{c}0.011 \\
(0.010)\end{array}$ & $\begin{array}{c}0.004 \\
(0.009)\end{array}$ & $\begin{array}{c}0.005 \\
(0.020)\end{array}$ & $\begin{array}{c}-0.024^{*} \\
(0.014)\end{array}$ \\
\hline God important & $\begin{array}{c}-0.002 \\
(0.001)\end{array}$ & $\begin{array}{c}0.002 \\
(0.001)\end{array}$ & $\begin{array}{c}0.005 \\
(0.003)\end{array}$ & $\begin{array}{c}-0.006 * * \\
(0.003)\end{array}$ \\
\hline Female & $\begin{array}{c}-0.007^{* *} \\
(0.003)\end{array}$ & $\begin{array}{l}-0.021^{* * *} \\
(0.005)\end{array}$ & $\begin{array}{c}0.014^{* *} \\
(0.007)\end{array}$ & $\begin{array}{l}-0.079^{* * *} \\
(0.008)\end{array}$ \\
\hline Age & $\begin{array}{l}-0.001^{* * *} \\
(0.001)\end{array}$ & $\begin{array}{c}-0.002 \\
(0.001)\end{array}$ & $\begin{array}{l}0.004^{* * *} \\
(0.002)\end{array}$ & $\begin{array}{l}-0.003^{* * *} \\
(0.001)\end{array}$ \\
\hline Age $^{2}$ & $\begin{array}{l}0.000^{* * *} \\
(0.000)\end{array}$ & $\begin{array}{c}0.000 \\
(0.000)\end{array}$ & $\begin{array}{l}-0.000^{* * *} \\
(0.000)\end{array}$ & $\begin{array}{l}0.000^{* * *} \\
(0.000)\end{array}$ \\
\hline White & $\begin{array}{l}\text { o.015** } \\
(0.007)\end{array}$ & $\begin{array}{c}0.004 \\
(0.008)\end{array}$ & $\begin{array}{l}-0.057^{* * *} \\
(0.020)\end{array}$ & $\begin{array}{c}-0.007 \\
(0.012)\end{array}$ \\
\hline Black & $\begin{array}{c}0.005 \\
(0.014)\end{array}$ & $\begin{array}{c}0.011 \\
(0.011)\end{array}$ & $\begin{array}{l}0.053^{* * *} \\
(0.017)\end{array}$ & $\begin{array}{c}0.044^{*} \\
(0.025)\end{array}$ \\
\hline East Asian & $\begin{array}{c}-0.015 \\
(0.016)\end{array}$ & $\begin{array}{c}0.035 \\
(0.025)\end{array}$ & $\begin{array}{l}0.083^{* * *} \\
(0.023)\end{array}$ & $\begin{array}{c}-0.003 \\
(0.046)\end{array}$ \\
\hline Other Asian or Arab & $\begin{array}{c}0.027^{*} \\
(0.016)\end{array}$ & $\begin{array}{c}0.014 \\
(0.016)\end{array}$ & $\begin{array}{c}-0.029 \\
(0.030)\end{array}$ & $\begin{array}{c}0.020 \\
(0.021)\end{array}$ \\
\hline Health & $\begin{array}{l}-0.000 \\
(0.002)\end{array}$ & $\begin{array}{c}-0.005^{*} \\
(0.003)\end{array}$ & $\begin{array}{c}-0.004 \\
(0.005)\end{array}$ & $\begin{array}{l}-0.001 \\
(0.003)\end{array}$ \\
\hline Married & $\begin{array}{c}0.003 \\
(0.005)\end{array}$ & $\begin{array}{c}-0.002 \\
(0.007)\end{array}$ & $\begin{array}{l}0.071^{* * *} \\
(0.015)\end{array}$ & $\begin{array}{c}0.010 \\
(0.008)\end{array}$ \\
\hline Living together & $\begin{array}{c}-0.008 * \\
(0.005)\end{array}$ & $\begin{array}{l}-0.018 \\
(0.012)\end{array}$ & $\begin{array}{l}0.053^{* * *} \\
(0.017)\end{array}$ & $\begin{array}{c}0.004 \\
(0.008)\end{array}$ \\
\hline
\end{tabular}




\begin{tabular}{|c|c|c|c|c|}
\hline & $\begin{array}{l}(1) \\
\text { Inadequate } \\
\text { education most } \\
\text { serious problem } \\
\text { of the world }\end{array}$ & $\begin{array}{l}(2) \\
\text { Inadequate } \\
\text { education most } \\
\text { serious problem } \\
\text { for their own } \\
\text { country }\end{array}$ & $\begin{array}{l}\text { (3) } \\
\text { Worried about } \\
\text { not being able } \\
\text { to give their } \\
\text { children a good } \\
\text { education }\end{array}$ & $\begin{array}{l}\text { (4) } \\
\text { University more } \\
\text { important for } \\
\text { a boy than for } \\
\text { a girl }\end{array}$ \\
\hline Divorced & $\begin{array}{c}0.007 \\
(0.008)\end{array}$ & $\begin{array}{c}0.013 \\
(0.013)\end{array}$ & $\begin{array}{c}0.028 \\
(0.021)\end{array}$ & $\begin{array}{c}0.012 \\
(0.013)\end{array}$ \\
\hline Separated & $\begin{array}{c}0.006 \\
(0.009)\end{array}$ & $\begin{array}{c}0.004 \\
(0.017)\end{array}$ & $\begin{array}{l}0.058^{* * *} \\
(0.022)\end{array}$ & $\begin{array}{l}0.028^{* *} \\
(0.014)\end{array}$ \\
\hline Widowed & $\begin{array}{l}-0.001 \\
(0.007)\end{array}$ & $\begin{array}{c}0.011 \\
(0.015)\end{array}$ & $\begin{array}{c}0.007 \\
(0.017)\end{array}$ & $\begin{array}{c}0.013 \\
(0.011)\end{array}$ \\
\hline Children & $\begin{array}{l}-0.000 \\
(0.001)\end{array}$ & $\begin{array}{c}0.002 \\
(0.002)\end{array}$ & $\begin{array}{l}0.017^{* * *} \\
(0.004)\end{array}$ & $\begin{array}{c}0.001 \\
(0.002)\end{array}$ \\
\hline Family important & $\begin{array}{l}-0.022 \\
(0.016)\end{array}$ & $\begin{array}{c}0.028 \\
(0.025)\end{array}$ & $\begin{array}{c}0.047 \\
(0.035)\end{array}$ & $\begin{array}{l}-0.061^{* * *} \\
(0.022)\end{array}$ \\
\hline Employed & $\begin{array}{l}-0.003 \\
(0.003)\end{array}$ & $\begin{array}{c}0.001 \\
(0.009)\end{array}$ & $\begin{array}{l}0.032^{* * *} \\
(0.008)\end{array}$ & $\begin{array}{l}-0.012^{* *} \\
(0.006)\end{array}$ \\
\hline Unemployed & $\begin{array}{l}-0.006 \\
(0.006)\end{array}$ & $\begin{array}{l}-0.014^{*} \\
(0.008)\end{array}$ & $\begin{array}{l}0.044^{* * *} \\
(0.014)\end{array}$ & $\begin{array}{c}0.004 \\
(0.007)\end{array}$ \\
\hline Town & $\begin{array}{c}0.002 \\
(0.001)\end{array}$ & $\begin{array}{c}0.002 \\
(0.001)\end{array}$ & $\begin{array}{l}-0.000 \\
(0.003)\end{array}$ & $\begin{array}{l}-0.002 \\
(0.002)\end{array}$ \\
\hline Country dummies & Yes & Yes & Yes & Yes \\
\hline Year dummies & Yes & No & No & Yes \\
\hline Number of observations & 57,965 & 20,052 & 36,926 & 59,445 \\
\hline $\begin{array}{l}\text { Number of countries } \\
\text { Pseudo } R^{2}\end{array}$ & 55 & 26 & 39 & 55 \\
\hline McFadden & 0.07 & 0.04 & 0.17 & 0.12 \\
\hline McKelvey and Zavoina & 0.13 & 0.09 & 0.31 & 0.25 \\
\hline
\end{tabular}

Note: Conditional marginal effects of probit regressions, calculated at the means. Robust standard errors, adjusted for clustering at the country level, are reported in parentheses. The data are from World Values Survey waves 5 (2005-09) and 6 (2010-14), except regression 2, which is based on data from wave 5 only, and regression 3, which is based on data from wave 6 only (Inglehart et al. 2015). ${ }^{* * *}\left({ }^{* *} / *\right)$ denotes statistically significant at the $1 \%(5 \% / 10 \%)$ level. 


\begin{tabular}{|c|c|c|c|c|}
\hline & $\begin{array}{l}(1) \\
\text { Inadequate } \\
\text { education most } \\
\text { serious problem } \\
\text { of the world }\end{array}$ & $\begin{array}{l}(2) \\
\text { Inadequate } \\
\text { education most } \\
\text { serious problem } \\
\text { for their own } \\
\text { country }\end{array}$ & $\begin{array}{l}\text { (3) } \\
\text { Worried about } \\
\text { not being able } \\
\text { to give their } \\
\text { children a good } \\
\text { education }\end{array}$ & $\begin{array}{l}\text { (4) } \\
\text { University more } \\
\text { important for } \\
\text { a boy than for } \\
\text { a girl }\end{array}$ \\
\hline Elementary education & $\begin{array}{c}0.013^{*} \\
(0.008)\end{array}$ & $\begin{array}{c}0.017 \\
(0.011)\end{array}$ & $\begin{array}{c}0.027 \\
(0.021)\end{array}$ & $\begin{array}{l}-0.011 \\
(0.012)\end{array}$ \\
\hline Middle education & $\begin{array}{l}0.027^{* * *} \\
(0.007)\end{array}$ & $\begin{array}{l}0.035^{* *} \\
(0.014)\end{array}$ & $\begin{array}{c}0.020 \\
(0.016)\end{array}$ & $\begin{array}{l}-0.063^{* * *} \\
(0.010)\end{array}$ \\
\hline Higher education & $\begin{array}{l}0.048^{* * *} \\
(0.010)\end{array}$ & $\begin{array}{l}0.050^{* * *} \\
(0.015)\end{array}$ & $\begin{array}{c}0.001 \\
(0.017)\end{array}$ & $\begin{array}{l}-0.113^{* * *} \\
(0.013)\end{array}$ \\
\hline Income & $\begin{array}{l}0.002^{* *} \\
(0.001)\end{array}$ & $\begin{array}{l}0.006^{* * *} \\
(0.001)\end{array}$ & $\begin{array}{l}-0.011^{* * *} \\
(0.003)\end{array}$ & $\begin{array}{c}0.001 \\
(0.003)\end{array}$ \\
\hline Middle class & $\begin{array}{l}0.014^{* * *} \\
(0.003)\end{array}$ & $\begin{array}{c}0.005 \\
(0.008)\end{array}$ & $\begin{array}{l}-0.004 \\
(0.013)\end{array}$ & $\begin{array}{l}-0.007 \\
(0.005)\end{array}$ \\
\hline Upper class & $\begin{array}{l}0.033^{* * *} \\
(0.006)\end{array}$ & $\begin{array}{l}-0.006 \\
(0.017)\end{array}$ & $\begin{array}{l}-0.052^{* *} \\
(0.021)\end{array}$ & $\begin{array}{l}0.034^{* *} \\
(0.017)\end{array}$ \\
\hline Political left & $\begin{array}{l}-0.005 \\
(0.005)\end{array}$ & $\begin{array}{l}-0.003 \\
(0.011)\end{array}$ & $\begin{array}{l}-0.014 \\
(0.010)\end{array}$ & $\begin{array}{l}-0.001 \\
(0.007)\end{array}$ \\
\hline Political right & $\begin{array}{c}0.002 \\
(0.005)\end{array}$ & $\begin{array}{l}-0.002 \\
(0.013)\end{array}$ & $\begin{array}{c}0.002 \\
(0.012)\end{array}$ & $\begin{array}{l}0.030^{* * *} \\
(0.006)\end{array}$ \\
\hline Postmaterialist & $\begin{array}{l}0.048^{* * *} \\
(0.009)\end{array}$ & $\begin{array}{l}0.052^{* * *} \\
(0.015)\end{array}$ & $\begin{array}{c}-0.009 \\
(0.018)\end{array}$ & $\begin{array}{l}-0.017 \\
(0.019)\end{array}$ \\
\hline Protestant & $\begin{array}{l}-0.010^{* *} \\
(0.005)\end{array}$ & $\begin{array}{l}-0.021^{* *} \\
(0.008)\end{array}$ & $\begin{array}{c}0.008 \\
(0.022)\end{array}$ & $\begin{array}{c}0.012 \\
(0.010)\end{array}$ \\
\hline Roman Catholic & $\begin{array}{l}-0.008 * \\
(0.005)\end{array}$ & $\begin{array}{l}-0.015 \\
(0.010)\end{array}$ & $\begin{array}{c}0.010 \\
(0.020)\end{array}$ & $\begin{array}{c}0.017^{*} \\
(0.010)\end{array}$ \\
\hline Eastern Orthodox & $\begin{array}{l}-0.024^{* *} \\
(0.010)\end{array}$ & $\begin{array}{c}-0.013 \\
(0.018)\end{array}$ & $\begin{array}{c}0.016 \\
(0.021)\end{array}$ & $\begin{array}{l}0.040^{* * *} \\
(0.014)\end{array}$ \\
\hline Other Christian & $\begin{array}{l}-0.024^{*} \\
(0.013)\end{array}$ & $\begin{array}{l}-0.007 \\
(0.018)\end{array}$ & $\begin{array}{l}-0.017 \\
(0.020)\end{array}$ & $\begin{array}{l}-0.032^{* *} \\
(0.014)\end{array}$ \\
\hline Jewish & $\begin{array}{c}0.033 \\
(0.021)\end{array}$ & $\begin{array}{c}0.017 \\
(0.050)\end{array}$ & $\begin{array}{l}0.165^{* * *} \\
(0.035)\end{array}$ & $\begin{array}{c}0.078 \\
(0.061)\end{array}$ \\
\hline Muslim & $\begin{array}{c}0.000 \\
(0.013)\end{array}$ & $\begin{array}{l}-0.033^{* *} \\
(0.014)\end{array}$ & $\begin{array}{c}0.042 \\
(0.029)\end{array}$ & $\begin{array}{l}0.061 \% * * \\
(0.021)\end{array}$ \\
\hline
\end{tabular}




\begin{tabular}{|c|c|c|c|c|}
\hline & $\begin{array}{l}\text { (1) } \\
\text { Inadequate } \\
\text { education most } \\
\text { serious problem } \\
\text { of the world }\end{array}$ & $\begin{array}{l}(2) \\
\text { Inadequate } \\
\text { education most } \\
\text { serious problem } \\
\text { for their own } \\
\text { country }\end{array}$ & $\begin{array}{l}(3) \\
\text { Worried about } \\
\text { not being able } \\
\text { to give their } \\
\text { children a good } \\
\text { education }\end{array}$ & $\begin{array}{l}\text { (4) } \\
\text { University more } \\
\text { important for } \\
\text { a boy than for } \\
\text { a girl }\end{array}$ \\
\hline Hindu & $\begin{array}{l}-0.012 \\
(0.020)\end{array}$ & $\begin{array}{l}-0.019 \\
(0.017)\end{array}$ & $\begin{array}{l}-0.037 \\
(0.035)\end{array}$ & $\begin{array}{c}0.012 \\
(0.022)\end{array}$ \\
\hline Buddhist & $\begin{array}{c}-0.027 \\
(0.018)\end{array}$ & $\begin{array}{l}-0.006 \\
(0.017)\end{array}$ & $\begin{array}{l}-0.003 \\
(0.039)\end{array}$ & $\begin{array}{l}0.120^{* * *} \\
(0.025)\end{array}$ \\
\hline Other Eastern religions & $\begin{array}{c}\text { o.054 } \\
(0.039)\end{array}$ & $\begin{array}{c}0.003 \\
(0.020)\end{array}$ & $\begin{array}{c}0.147 \\
(0.270)\end{array}$ & $\begin{array}{l}-0.011 \\
(0.050)\end{array}$ \\
\hline Other religions & $\begin{array}{c}0.012 \\
(0.010)\end{array}$ & $\begin{array}{c}0.003 \\
(0.012)\end{array}$ & $\begin{array}{c}0.000 \\
(0.020)\end{array}$ & $\begin{array}{l}-0.025 \\
(0.015)\end{array}$ \\
\hline God important & $\begin{array}{l}-0.002 \\
(0.001)\end{array}$ & $\begin{array}{l}0.003^{* *} \\
(0.001)\end{array}$ & $\begin{array}{c}0.005 \\
(0.003)\end{array}$ & $\begin{array}{l}-0.007^{* *} \\
(0.003)\end{array}$ \\
\hline Female & $\begin{array}{l}-0.006 * * \\
(0.003)\end{array}$ & $\begin{array}{l}-0.021 \% * * \\
(0.005)\end{array}$ & $\begin{array}{l}0.018^{* *} \\
(0.007)\end{array}$ & $\begin{array}{l}-0.076^{* * *} \\
(0.008)\end{array}$ \\
\hline Age & $\begin{array}{l}-0.001 \% * * \\
(0.001)\end{array}$ & $\begin{array}{c}-0.002 \\
(0.001)\end{array}$ & $\begin{array}{l}0.004^{* * *} \\
(0.002)\end{array}$ & $\begin{array}{l}-0.003^{* * *} \\
(0.001)\end{array}$ \\
\hline $\mathrm{Age}^{2}$ & $\begin{array}{l}0.000^{* *} \\
(0.000)\end{array}$ & $\begin{array}{c}0.000 \\
(0.000)\end{array}$ & $\begin{array}{l}-0.000^{* * *} \\
(0.000)\end{array}$ & $\begin{array}{l}0.000^{* * *} \\
(0.000)\end{array}$ \\
\hline White & $\begin{array}{l}0.016 * * \\
(0.007)\end{array}$ & $\begin{array}{c}0.005 \\
(0.008)\end{array}$ & $\begin{array}{l}-0.057^{* * *} \\
(0.021)\end{array}$ & $\begin{array}{l}-0.011 \\
(0.012)\end{array}$ \\
\hline Black & $\begin{array}{c}0.004 \\
(0.014)\end{array}$ & $\begin{array}{c}0.011 \\
(0.011)\end{array}$ & $\begin{array}{l}0.052^{* * *} \\
(0.018)\end{array}$ & $\begin{array}{c}0.043^{*} \\
(0.025)\end{array}$ \\
\hline East Asian & $\begin{array}{c}\text { O.000 } \\
(0.019)\end{array}$ & $\begin{array}{c}0.038 \\
(0.026)\end{array}$ & $\begin{array}{l}0.109 * * \\
(0.053)\end{array}$ & $\begin{array}{c}-0.044 \\
(0.047)\end{array}$ \\
\hline Other Asian or Arab & $\begin{array}{c}0.032^{*} \\
(0.018)\end{array}$ & $\begin{array}{c}0.014 \\
(0.017)\end{array}$ & $\begin{array}{l}-0.028 \\
(0.037)\end{array}$ & $\begin{array}{c}0.011 \\
(0.021)\end{array}$ \\
\hline Health & $\begin{array}{l}-0.001 \\
(0.002)\end{array}$ & $\begin{array}{l}-0.005^{*} \\
(0.003)\end{array}$ & $\begin{array}{l}-0.006 \\
(0.005)\end{array}$ & $\begin{array}{l}-0.002 \\
(0.004)\end{array}$ \\
\hline Married & $\begin{array}{c}0.004 \\
(0.005)\end{array}$ & $\begin{array}{c}-0.004 \\
(0.007)\end{array}$ & $\begin{array}{l}0.076^{* * *} \\
(0.016)\end{array}$ & $\begin{array}{c}0.010 \\
(0.008)\end{array}$ \\
\hline Living together & $\begin{array}{c}-0.006 \\
(0.005)\end{array}$ & $\begin{array}{l}-0.018 \\
(0.013)\end{array}$ & $\begin{array}{l}0.057^{* * *} \\
(0.018)\end{array}$ & $\begin{array}{c}0.005 \\
(0.008)\end{array}$ \\
\hline Divorced & $\begin{array}{c}0.010 \\
(0.008)\end{array}$ & $\begin{array}{l}0.021 * \\
(0.012)\end{array}$ & $\begin{array}{c}0.033 \\
(0.023)\end{array}$ & $\begin{array}{c}0.014 \\
(0.014)\end{array}$ \\
\hline
\end{tabular}




\begin{tabular}{|c|c|c|c|c|}
\hline & $\begin{array}{l}\text { (1) } \\
\text { Inadequate } \\
\text { education most } \\
\text { serious problem } \\
\text { of the world }\end{array}$ & $\begin{array}{l}(2) \\
\text { Inadequate } \\
\text { education most } \\
\text { serious problem } \\
\text { for their own } \\
\text { country }\end{array}$ & $\begin{array}{l}\text { (3) } \\
\text { Worried about } \\
\text { not being able } \\
\text { to give their } \\
\text { children a good } \\
\text { education }\end{array}$ & $\begin{array}{l}\text { (4) } \\
\text { University more } \\
\text { important for } \\
\text { a boy than for } \\
\text { a girl }\end{array}$ \\
\hline Separated & $\begin{array}{c}0.008 \\
(0.009)\end{array}$ & $\begin{array}{c}0.003 \\
(0.019)\end{array}$ & $\begin{array}{l}0.065^{* * *} \\
(0.022)\end{array}$ & $\begin{array}{c}0.027^{*} \\
(0.014)\end{array}$ \\
\hline Widowed & $\begin{array}{c}0.002 \\
(0.007)\end{array}$ & $\begin{array}{c}0.011 \\
(0.017)\end{array}$ & $\begin{array}{c}0.006 \\
(0.019)\end{array}$ & $\begin{array}{c}0.015 \\
(0.012)\end{array}$ \\
\hline Children & $\begin{array}{l}-0.001 \\
(0.001)\end{array}$ & $\begin{array}{c}0.002 \\
(0.002)\end{array}$ & $\begin{array}{l}0.017^{* * *} \\
(0.004)\end{array}$ & $\begin{array}{c}0.002 \\
(0.002)\end{array}$ \\
\hline Family important & $\begin{array}{l}-0.021 \\
(0.016)\end{array}$ & $\begin{array}{c}0.031 \\
(0.026)\end{array}$ & $\begin{array}{c}0.049 \\
(0.036)\end{array}$ & $\begin{array}{l}-0.064^{* * *} \\
(0.023)\end{array}$ \\
\hline Employed & $\begin{array}{l}-0.003 \\
(0.003)\end{array}$ & $\begin{array}{c}0.001 \\
(0.009)\end{array}$ & $\begin{array}{l}0.033^{* * *} \\
(0.008)\end{array}$ & $\begin{array}{l}-0.015^{* *} \\
(0.006)\end{array}$ \\
\hline Unemployed & $\begin{array}{l}-0.007 \\
(0.006)\end{array}$ & $\begin{array}{l}-0.013^{*} \\
(0.008)\end{array}$ & $\begin{array}{l}0.050^{* * *} \\
(0.013)\end{array}$ & $\begin{array}{c}0.002 \\
(0.007)\end{array}$ \\
\hline Town & $\begin{array}{c}0.001 \\
(0.001)\end{array}$ & $\begin{array}{c}0.002 \\
(0.001)\end{array}$ & $\begin{array}{l}-0.002 \\
(0.002)\end{array}$ & $\begin{array}{l}-0.001 \\
(0.002)\end{array}$ \\
\hline GDP per capita & $\begin{array}{c}0.047 \\
(0.033)\end{array}$ & $\begin{array}{l}-0.088^{* * *} \\
(0.026)\end{array}$ & $\begin{array}{l}0.257^{* * *} \\
(0.030)\end{array}$ & $\begin{array}{c}0.036 \\
(0.104)\end{array}$ \\
\hline Country dummies & Yes & Yes & Yes & Yes \\
\hline Year dummies & Yes & No & No & Yes \\
\hline Number of observations & 53,943 & 18,100 & 33,790 & 54,305 \\
\hline $\begin{array}{l}\text { Number of countries } \\
\text { Pseudo } R^{2}\end{array}$ & $5^{\circ}$ & 24 & 35 & $5^{\circ}$ \\
\hline McFadden & 0.06 & 0.04 & 0.18 & 0.12 \\
\hline McKelvey and Zavoina & 0.12 & 0.09 & 0.32 & 0.24 \\
\hline
\end{tabular}

Note: Conditional marginal effects of probit regressions, calculated at the means. Robust standard errors, adjusted for clustering at the country level, are reported in parentheses. The data are from World Values Survey waves 5 (2005-09) and 6 (2010-14), except regression 2, which is based on data from wave 5 only, and regression 3, which is based on data from wave 6 only (Inglehart et al. 2015). Data on 'GDP per capita' are from Feenstra et al. (2019). ${ }^{* * *}\left({ }^{* *} / *\right)$ denotes statistically significant at the $1 \%(5 \% / 10 \%)$ level. 
Tables 2 and 3 report conditional marginal effects of probit regressions, calculated at the means. Whereas Table 2 reports the results from our baseline specification, Table 3 reports the results from our main robustness check, which additionally includes 'GDP per capita'. Tables 2 and 3 also report two goodnessof-fit measures. The first is the most commonly used Pseudo $R^{2}$ constructed by McFadden (1973). As this measure has been found to have a downward bias (e.g., Veall and Zimmermann 1996), we additionally report the Pseudo $R^{2}$ constructed by McKelvey and Zavoina (1975). The latter is often regarded as the best fit measure for limited dependent variable models (e.g., Veall and Zimmermann 1996, Long 1997). It also has the advantage of being most comparable to $R^{2}$ from oLs regressions (e.g., Veall and Zimmermann 1996). Anyhow, in our case both McFadden's as well as McKelvey and Zavoina's Pseudo $R^{2}$ suggest that our model has a very good fit when using the third dependent variable and a good fit when using the fourth (Tables 2 and 3). By contrast, the fit is much weaker when using the first and especially when using the second dependent variable.

Remarkably, the estimates for our individual-level variables are very robust across both specifications - in spite of the fact that the regressions of our main robustness check not only additionally include a country-level variable but are also based on fewer countries and observations.

A first insight from our analysis is that, in line with expectations, respondents who had received more education attached greater importance to it (Tables 2 and 3). In fact, the probability of regarding inadequate education as the most serious problem of either the world or one's own country rose with the level of education attained. For example, while respondents with middle education were roughly $2 \frac{1}{2}$ percentage points more likely than respondents with inadequately completed elementary education to view inadequate education as the most serious problem of the world, respondents with higher education were about $4^{1 / 2}$ percentage points more likely to do so. This pattern is repeated for attitudes toward gender equality in university education. While respondents with middle education were roughly 6 percentage points less likely to view university as more important for a boy than for a girl, respondents with higher education were about 11 percentage points less likely to do so.

For those who have not yet completed their education, their educational views may affect their attainment. For example, those who hold education in high regard may acquire more of it. This reverse causality could have biased our estimates of the educational attainment variables. Therefore, we performed a further robustness check in which we excluded respondents below 
the age of 25 and re-ran all eight regressions. Almost everybody aged 25 and above has completed their education. As Table Ar in the Appendix documents, the results from this robustness check are almost identical to the ones reported in Tables 2 and 3. Thus, the results reported in these tables are not biased by reverse causality.

The estimates for 'income' suggest that regard for education rose not only with attainment but also with respondents' household income, relative to income levels in their own country (Tables 2 and 3). Specifically, the higher their relative income, the more likely they were to consider inadequate education to be the most serious problem of either the world or their own country. Agreement with the country statement rose particularly strongly with respondents' relative income position. On the other hand, the coefficient on 'income' is statistically insignificant in the regressions of gender equality, indicating that respondents on relatively higher income were no more likely to favor gender equality in university education. At the same time, they were less worried about their ability to provide their children with a good education, obviously because they could more easily afford to send them to a private school and provide them with out-of-school tuition.

We find three interesting effects of social class on educational attitudes. First and unsurprisingly, respondents from the upper class were less concerned than respondents from the working class about their ability to provide their children with a good education. Second, the higher their social class, the more likely respondents were to deem inadequate education to be the most serious problem of the world. Third and somewhat embarrassingly, respondents from the upper class were more likely to view university education as being relatively unimportant for girls. Hence, whereas members of this class were comparatively strongly in favor of education in general, they were less in favor of gender equality in university education than respondents from the working class.

This third result chimes with a result we obtained with respect to the impact of political views on educational attitudes. Namely and in this case unsurprisingly, members with right-wing views were more likely than members with centrist views to regard university education as being relatively unimportant for girls. With respect to the impact of political views, it is also noteworthy that respondents with left-wing views did not attach greater importance to education than respondents with centrist views.

The latter result is in stark contrast to our main result for 'postmaterialist'. The more strongly respondents adhered to postmaterialist values, the more they tended to agree with the statements that inadequate education was the most serious problem of either the world or their own country. However, and a 
bit surprisingly, postmaterialists did not see gender equality in university education as more important than materialists did.

With respect to religion, we find that adherents to all Christian denominations were less likely than non-religious respondents to consider inadequate education to be the most serious problem of the world. Protestants were also less likely to consider inadequate education to be the most serious problem for their own country. The results for Protestants may seem surprising. Whereas Roman Catholicism and Eastern Orthodoxy have never emphasized education of the masses, Protestantism has (Feldmann 2016a). It was a key ambition of the Reformation to educate children of all social classes, both boys and girls. From the 16th century until the secularization of education in the 19th century, Protestantism was the driving force behind mass education in traditionally Protestant countries (Feldmann 2018). In Britain's colonies, it remained so until decolonization (Feldmann 2016b). Yet, since the mid-2oth century the traditional Protestant emphasis on education has largely vanished, partly due to a rapid rise of Pentecostalism, which has become an influential branch of Protestantism. Pentecostals are more given to spiritual experience and feelings. The mystic character of Pentecostalism (e.g., speaking in tongues, belief in miracles) is not conducive to secular education (Feldmann 2018). Some Pentecostals even oppose educating their children in public schools (Sikkink 1999). Hence, the negative coefficients on 'Protestant' in our regressions reflect that most Protestants no longer see education as an important issue. According to our research, Protestants were not even more likely than non-religious respondents to favor gender equality in university education, in stark contrast to their own history.

Many Muslim respondents were even significantly more likely to agree with the notion that university is more important for a boy than for a girl. This finding is not new. Also using World Values Survey data, both Guiso et al. (2003) and Fish (2011) have found the same. Numerous other studies using other data have also found Islam to negatively affect female education (e.g., Norton and Tomal 2009, Mukhopadhyay 2011).

In our research, Muslims were not the only religious respondents who had a negative opinion of gender equality in university education. Adherents to Eastern Orthodoxy and Buddhism were also more likely to agree with the relevant statement. This is probably mainly because, similar to Islam, many adherents to those religions have a conservative worldview (e.g., Vrame 2006, Fox and Gamage 2011, Gamage and Setunga 2011). Our interpretation that a negative view of gender equality in university education is probably mainly due to such a worldview, rather than to adherence to a particular religion, is 
supported by our finding that more strongly religious respondents were less likely to agree with the relevant statement. Moreover, in a supplementary regression that additionally includes interaction terms between our religiosity variable, on the one hand, and each of the three religion adherence variables, on the other, we find each of these terms to be statistically insignificant (results not reported here) - a finding that supports our interpretation as well.

A final result for our religion variables is worth noting. Jews were the only religious respondents who were more likely than non-religious respondents to be worried about not being able to give their children a good education. This may reflect the fact that Jews have always cherished education (Botticini and Eckstein 2012). The Torah is replete with dicta to "teach your children diligently" about Jewish mores and history (Zeldin 2011). Nowadays, Jews still take the education of their children very seriously.

There are three interesting results for female respondents. First, they were more likely than male respondents to be concerned about their ability to provide their children with a good education. Second, they were more likely to disagree with the notion that university education is more important for a boy than for a girl. Third, they were less likely than men to deem inadequate education to be the most serious problem of either the world or their own country. Taken together, these results suggest that women are more concerned about the education of their children than about education in general and that the only general educational issue they strongly care about is gender equality.

We find three effects of age on respondents' views of education. First, from the age of 50 onwards respondents tended to agree that inadequate education was the most serious problem of the world. Second, from the age of 44 onwards respondents were more likely to consider university as more important for a boy than for a girl. In both cases, these views strengthened with increasing age. Note that the simultaneous occurrence of both views chimes with those of respondents from the upper class. Third and surprisingly, from as early as 21 onwards respondents worried increasingly less about not being able to give their children a good education.

Our estimates for the ethnicity variables also provide several insights. First, Whites and the group "Other Asian and Arab" were comparatively more likely to regard inadequate education as the most serious problem of the world. Second, Whites were comparatively less concerned about their ability to provide their children with a good education. Many of them were probably better off and better connected. Blacks, on the other hand, were comparatively more concerned, probably because, in many countries, most members of this group are socially deprived (e.g., Cutler and Glaeser 1997). 
A further insight from our ethnicity estimates is that East Asians were even more likely than Blacks to be concerned about not being able to give their children a good education. This result reflects the high value East Asian parents place on their children's education. Note that, in our data, East Asians were no more likely than the reference group to regard inadequate education as the most pressing problem of either the world or their own country. Thus they were no more likely to place a high value on education in general. Rather, they were primarily concerned about the education of their children.

Our estimates in the area of marital status and family reveal that not only married respondents but also those living together or separated were more likely than singles to worry about not being able to give their children a good education. A larger number of children increased such worries too. The latter result as well as the result for married people are plausible. The fact that respondents living together were also more likely to have such worries is understandable because, in many countries, a large share of children are nowadays born out of wedlock (e.g., OECD 2018). Moreover, the result for separated respondents is comprehensible because being separated may mean having less influence on children someone has with their former partner. A further interesting result in the area of marital status and family is that respondents to whom family was important were more likely than others to be in favor of gender equality in university education. At the same time, neither those with many children nor those who regarded family as important were more likely to highly value education in general, similar to East Asians.

With respect to employment status, we find that both employed as well as unemployed respondents were more likely than non-employed respondents to worry about their ability to provide their children with a good education. This confirms our expectations (section 2.2). Additionally, we find that employed respondents were more likely to disagree with the notion that university is more important for a boy than for a girl, perhaps because they were less conservative than the non-employed.

There are two insights from the estimates for 'GDP per capita', the countrylevel variable we add in our main robustness check (Table 3). First, with rising GDP per capita fewer respondents regarded inadequate education as the most serious problem for their own country. Second, at the same time they became more concerned about their ability to provide their children with a good education. The first result is comprehensible because richer countries have more resources to provide good education. The second result may seem surprising though. However, in several rich and middle-income countries such as Japan, South Korea, China and India many parents are exceptionally concerned not only about their children's academic achievement but also about getting them 
into the best schools and colleges (e.g., Bossy 2000, Pew Research Center 2011). The reputation of the college a student is admitted to can make a huge difference for their career and earnings throughout the rest of their life.

\section{4}

\section{Conclusion}

Using World Values Survey data from 55 countries, this article provides detailed insights into the characteristics of people who place a high value on education - as well as into the characteristics of those who don't. It documents that respondents were more likely to regard inadequate education as the most serious problem of the world if they had attained middle or higher education, had a relatively high income, were from the middle or upper class, held postmaterialist values, were relatively old and/or were of White, Arab or Asian (but not East-Asian) ethnicity. By contrast, those who had attained little education, had relatively low income, were from the working class and/or held materialist values were unlikely to share this view. And so were females, Christians and relatively young people.

Furthermore, we find that respondents were more likely to favor gender equality in university education if they were female, relatively young, employed, religious and/or had attained middle or higher education. By contrast, those who were male, relatively old, from the upper class, held right-wing political views and/or adhered to Islam, Buddhism or Eastern Orthodoxy were less likely to favor it.

Finally, respondents more likely to worry about not being able to give their children a good education were on comparatively low income and/or female, Jewish, of Black or East-Asian ethnicity, had many children and/or lived in a country with a relatively high income. Married respondents, those living together with their partner or separated were more likely to worry about this issue than those with a different marital status. Both those who were employed as well as those who were unemployed were more likely to worry about it than those who were not in the labor force. By contrast, those who were on high income, from the upper class and/or white were unlikely to worry about this issue.

By drawing such a detailed picture, we go well beyond the previous literature, which has looked at only a few characteristics. Another value added of our article is that it uses nationally representative data from a large sample of countries. By contrast, almost all previous papers have used data from a single country and in no case were the data nationally representative. 
Our insights can help domestic policy-makers and, in developing countries, foreign donors and the UN to gather support for educational initiatives in a more targeted way. This could increase the prospects of success for such initiatives. For example, a policy initiative for gender equality in university education should both secure the support of those most likely to favor it (e.g., females) and address the concerns of those most likely to oppose it (e.g., those with right-wing political views).

Although our article goes well beyond the previous literature and provides a host of insights, many of which could be relevant for policy-making, more research is needed. For example, future research should both cover more countries and track the evolution of people's educational views over time. Furthermore, the reasons why people with certain characteristics hold specific views need to be studied. Finally, the consequences of variations in attitudes toward education for the quantity and quality of educational investment undertaken need to be explored, both theoretically and empirically. As education is beneficial to both the individual and society, a better understanding of these issues is an important task for research going forward.

\section{References}

Alderman, Harold, John Hoddinott and Bill Kinsey (2006), Long Term Consequences of Early Childhood Malnutrition, Oxford Economic Papers, Vol. 58, No. 3, pp. 450-474.

Alexander, Karl L., Doris R. Entwisle and Samuel D. Bedinger (1994), When Expectations Work: Race and Socioeconomic Differences in School Performance, Social Psychology Quarterly, Vol. 57, No. 4, pp. 283-299.

Becker, Gary S. (1993 [1964]), Human Capital: A Theoretical and Empirical Analysis with Special Reference to Education, 3rd ed., Chicago (IL): University of Chicago Press.

Becker, Gary S. and H. Gregg Lewis (1973), On the Interaction between the Quantity and Quality of Children, Journal of Political Economy, Vol. 81, No. 2, Pt. 2, pp. S279-S288.

Becker, Gary S. and Nigel Tomes (1976), Child Endowments and the Quantity and Quality of Children, Journal of Political Economy, Vol. 84, No. 4, Pt. 2, pp. S143-S162.

Black, Sandra E. (1999), Do Better Schools Matter? Parental Valuation of Elementary Education, Quarterly Journal of Economics, Vol. 114, No. 2, pp. 577-599.

Bossy, Steve (2000), Academic Pressure and Impact on Japanese Students, McGill Journal of Education, Vol. 35, No. 1, pp. 71-89.

Botticini, Maristella and Zvi Eckstein (2012), The Chosen Few: How Education Shaped Jewish History, 70-1492, Princeton (NJ): Princeton University Press.

Bradley, Tamsin and Rubina Saigol (2012), Religious Values and Beliefs and Education for Women in Pakistan, Development in Practice, Vol. 22, No. 5-6, pp. 675-688. 
Cook, Philip J. and Jens Ludwig (1997), Weighing the "Burden of 'Acting White"': Are There Race Differences in Attitudes toward Education? Journal of Policy Analysis and Management, Vol. 16, No. 2, pp. 256-278.

Cooper, Linda (2017), The Maternal Gift: Mothers' Investment in their Daughters' Higher Education, Journal of Further and Higher Education, Vol. 41, No. 3, pp. 328-339.

Croll, Paul, Gaynor Attwood, Carol Fuller and Kathryn Last (2008), The Structure and Implications of Children's Attitudes to School, British Journal of Educational Studies, Vol. 56, No. 4, pp. 382-399.

Cutler, David M. and Edward L. Glaeser (1997), Are Ghettos Good or Bad? Quarterly Journal of Economics, Vol. 112, No. 3, pp. 827-872.

Davis-Kean, Pamela E. (2005), The Influence of Parent Education and Family Income on Child Achievement: The Indirect Role of Parental Expectations and the Home Environment, Journal of Family Psychology, Vol. 19, No. 2, pp. 294-304.

Day Ashley, Laura et al. (2014), The Role and Impact of Private Schools in Developing Countries: A Rigorous Review of the Evidence, London: Department for International Development.

Durkheim, Emile (1956), Education and Sociology, Glencoe (IL): Free Press.

Elacqua, Gregory, Maria Luisa Iribarren and Humberto Santos (2018), Private Schooling in Latin America: Trends and Public Policies, Washington, D.C.: Inter-American Development Bank.

Feenstra, Robert C., Robert Inklaar and Marcel P. Timmer (2019), Penn World Table 9.1. Available at https://www.rug.nl/ggdc/productivity/pwt/, accessed 12 April 2019.

Feldmann, Horst (2016a), Which Religions Still Affect Schooling? A Study of 143 Countries, Comparative Sociology, Vol. 15, No. 4, pp. 439-484.

Feldmann, Horst (2016b), The Long Shadows of Spanish and French Colonial Education, Kyklos, Vol. 69, No. 1, pp. 32-64.

Feldmann, Horst (2018), Still Influential: The Protestant Emphasis on Schooling, Comparative Sociology, Vol. 17, No. 5, pp. 641-678.

Fish, M. Steven (2011), Are Muslims Distinctive? A Look at the Evidence, Oxford: Oxford University Press.

Fladmoe, Audun (2012), Mass Political Polarization and Attitudes towards Education as Part of the Welfare State in Norway, Sweden and Finland, Journal of European Social Policy, Vol. 22, No. 1, pp. 45-62.

Fox, Pachrapimon Sooksomchitra and David T. Gamage (2011), Thailand: The Development of the Education System Since 1220, in: Yong Zhao, Jing Lei, Guofang Li, Ming Fang He, Kaori Okano, Nagwa Megahed, David Gamage and Hema Ramanathan (eds.), Handbook of Asian Education: A Cultural Perspective, New York: Routledge, pp. 425-441. 
Francis, Becky and Louise Archer (2005), British-Chinese Pupils' and Parents' Constructions of the Value of Education, British Educational Research Journal, Vol. 31, No. 1, pp. 89-108.

Fullerton, Andrew S. and Jeffrey C. Dixon (2010), Generational Conflict or Methodological Artifact? Public Opinion Quarterly, Vol. 74, No. 4, pp. 643-673.

Gamage, David T. and Prasad Setunga (2011), Developments in the Sri Lankan System of Education: Third Century BC to the Twenty-First Century AD, in: Yong Zhao, Jing Lei, Guofang Li, Ming Fang He, Kaori Okano, Nagwa Megahed, David Gamage and Hema Ramanathan (eds.), Handbook of Asian Education: A Cultural Perspective, New York: Routledge, pp. 403-424.

Gandhi Kingdon, Geeta (2017), The Private Schooling Phenomenon in India: A Review, Discussion Paper No. 10612, Bonn: IZA.

Gorman, Thomas J. (1998), Social Class and Parental Attitudes toward Education: Resistance and Conformity to Schooling in the Family, Journal of Contemporary Ethnography, Vol. 27, No. 1, pp. 10-44.

Guiso, Luigi, Paola Sapienza and Luigi Zingales (2003), People's Opium? Religion and Economic Attitudes, Journal of Monetary Economics, Vol. 5o, No. 1, pp. 225-282.

Hanushek, Eric A. (1992), The Trade-off between Child Quantity and Quality, Journal of Political Economy, Vol. 100, No. 1, pp. 84-117.

Hanushek, Eric A. and Ludger Woessmann (2016), Knowledge Capital, Growth and the East Asian Miracle, Science, Vol. 351, No. 6271, pp. 344-345.

Hastings, Justine S., Thomas J. Kane and Douglas O. Staiger (2006), Parental Preferences and School Competition: Evidence from a Public School Choice Program, NBER Working Paper No. 11805, Cambridge (MA): NBER.

Haveman, Robert and Barbara Wolfe (1995), The Determinants of Children's Attainments: A Review of Methods and Findings, Journal of Economic Literature, Vol. 33, No. 4, pp. 1829-1878.

Hoover-Dempsey, Kathleen V. and Howard M. Sandler (1997), Why Do Parents Become Involved in Their Children's Education? Review of Educational Research, Vol. 67, No. 1, pp. 3-42.

Inglehart, Ronald F. (1977), The Silent Revolution: Changing Values and Political Styles among Western Publics, Princeton (NJ): Princeton University Press.

Inglehart, Ronald F. (1990), Cultural Shift in Advanced Industrial Society, Princeton (NJ): Princeton University Press.

Inglehart, Ronald F. (1997), Modernization and Postmodernization: Cultural, Economic and Political Change in 43 Societies, Princeton (NJ): Princeton University Press.

Inglehart, Ronald F. (2018), Modernization, Existential Security and Cultural Change: Reshaping Human Motivations and Society, in: Michele J. Gelfand, Chi-yue Chiu and Ying-yi Hong (eds.), Handbook of Advances in Culture and Psychology, Vol. 7, Oxford: Oxford University Press, pp. 1-59. 
Inglehart, Ronald F. et al. (2015), World Values Survey. Longitudinal Data (1981-2014). Available at http://www.worldvaluessurvey.org, accessed 27 June 2017.

Jacob, Brian A. and Lars Lefgren (2007), What Do Parents Value in Education? An Empirical Investigation of Parents' Revealed Preferences for Teachers, Quarterly Journal of Economics, Vol. 122, No. 4, pp. 16o3-1637.

Jayachandran, Seema and Adriana Lleras-Muney (20o9), Life Expectancy and Human Capital Investments: Evidence from Maternal Mortality Declines, Quarterly Journal of Economics, Vol. 124, No. 1, pp. 349-397.

Jerrim, John (2015), Why Do East Asian Children Perform so Well in PISA? An Investigation of Western-Born Children of East Asian Descent, Oxford Review of Education, Vol. 41, No. 3, pp. 310-333.

Johnson, Richard and Joe Kotrlik (2012), Value of Education as Perceived by Mexican Immigrants and Caucasian American Citizens Employed in Agriculture in Louisiana, Journal of International Agricultural and Extension Education, Vol. 19, No. 2, pp. 14-26.

Kang, Changhui (2011), Family Size and Educational Investments in Children: Evidence from Private Tutoring Expenditures in South Korea, Oxford Bulletin of Economics and Statistics, Vol. 73, No. 1, pp. 59-78.

Khamis, Vivian, Samir Dukmak and Hala Elhoweris (2008), Factors Affecting the Motivation to Learn among United Arab Emirates Middle and High School Students, Educational Studies, Vol. 34, No. 3, pp. 191-200.

Kinloch, Graham C. (1987), Social Class and Attitudes toward Education, Journal of Social Psychology, Vol. 127, No. 4, pp. 399-401.

Knight, John and Shi Li (1996), Educational Attainment and the Rural-Urban Divide in China, Oxford Bulletin of Economics and Statistics, Vol. 58, No. 1, pp. 83-117.

Kong, Peggy A. (2010), “To Walk Out”: Rural Parents' Views on Education, China: An International Journal, Vol. 8, No. 2, pp. 36o-373.

Kooij, Dorien T. A. M. and Hannes Zacher (2016), Why and When Do Learning Goal Orientation and Attitude Decrease with Aging? The Role of Perceived Remaining Time and Work Centrality, Journal of Social Issues, Vol. 72, No. 1, pp. 146-168.

Lee, Jong-Wha and Hanol Lee (2016), Human Capital in the Long Run, Journal of Development Economics, Vol. 122, pp. 147-169.

Lee, Thomas H. C. (200o), Education in Traditional China: A History, Leiden: Brill.

Liu, Zhiqiang (2003), The Economic Impact and Determinants of Investment in Human and Political Capital in China, Economic Development and Cultural Change, Vol. 51, No. 4, pp. 823-849.

Long, J. Scott (1997), Regression Models for Categorical and Limited Dependent Variables, Thousand Oaks (CA): Sage.

McFadden, Daniel (1973), Conditional Logit Analysis of Qualitative Choice Behavior, in: Paul Zarembka (ed.), Frontiers in Econometrics, New York: Academic Press, pp. 105-142. 
McKelvey, Richard D. and William Zavoina (1975), A Statistical Model for the Analysis of Ordinal Level Dependent Variables, Journal of Mathematical Sociology, Vol. 4, No. 1, pp. 103-120.

Mukhopadhyay, Sankar (2011), Religion, Religiosity and Educational Attainment of Immigrants to the USA, Review of Economics of the Household, Vol. 9, No. 4, pp. 539-553.

Njagi, Simon Njogu, Joash A. Migosi and Jonathan M. Mwania (2014), Parental Involvement, Parenting Style, Secondary School Student Attitude towards Schooling and Academic Performance in Kenya, International Journal of Education Economics and Development, Vol. 5, No. 2, pp. 152-171.

Norton, Seth W. and Annette Tomal (2009), Religion and Female Educational Attainment, Journal of Money, Credit and Banking, Vol. 41, No. 5, pp. 961-986.

OECD (2015), PISA 2015 Results, Vol. 1: Excellence and Equity in Education, Paris: OECD.

OECD (2018), SF2.4: Share of Births Outside of Marriage. Available at http://www.oecd. org/els/family/database.htm, accessed 24 July 2019.

Pew Research Center (2011), Americans Want More Pressure on Students, the Chinese Want Less, Washington, D.C.: Pew Research Center.

Ponczek, Vladimir and Andre Portela Souza (2012), New Evidence of the Causal Effect of Family Size on Child Quality in a Developing Country, Journal of Human Resources, Vol. 47, No. 1, pp. 64-106.

Psacharopoulos, George and Harry Antony Patrinos (2018), Returns to Investment in Education: A Decennial Review of the Global Literature, Education Economics, Vol. 26, No. 5, pp. 445-458.

Rainey, Daniel V. and Olga Murova (2004), Factors Influencing Education Achievement, Applied Economics, Vol. 36, No. 21, pp. 2397-2404.

Ryan, Carey S., Juan F. Casas, Lisa Kelly-Vance, Brigitte O. Ryalls and Collette Nero (2010), Parent Involvement and Views of School Success: The Role of Parents' Latino and White American Cultural Orientations, Psychology in the School, Vol. 47, No. 4, pp. 391-405.

Schultz, Theodore W. (1963), The Economic Value of Education, New York: Columbia University Press.

Sikkink, David (1999), The Social Sources of Alienation from Public Schools, Social Forces, Vol. 78, No. 1, pp. 51-86.

Soares, Rodrigo R. (2005), Mortality Reductions, Educational Attainment and Fertility Choice, American Economic Review, Vol. 95, No. 3, pp. 580-6o1.

Spera, Christopher, Kathryn R. Wentzel and Holly C. Matto (2009), Parental Aspirations for their Children's Educational Attainment: Relations to Ethnicity, Parental Education, Children's Academic Performance and Parental Perceptions of School Climate, Journal of Youth and Adolescence, Vol. 38, No. 8, pp. 1140-1152. 
Starr, Don (2012), China and the Confucian Education Model. Available at http://www. universitas21.com, accessed 4 September 2015.

Strand, Steve (2007), Surveying the Views of Pupils Attending Supplementary Schools in England, Educational Research, Vol. 49, No. 1, pp. 1-20.

To, Cho-Yee (1993), Confucianism in East Asia, in: Witold Tulasiewicz and Cho-Yee To (eds.), World Religions and Educational Practice, London: Cassell, pp. 72-83.

Tooley, James (2013), The Beautiful Tree: A Personal Journey into How the World's Poorest People Are Educating Themselves, Washington, D.C.: Cato Institute.

United Nations (2015), Transforming our World: The 2030 Agenda for Sustainable Development. Available at https://sustainabledevelopment.un.org/post2015/transformingourworld, accessed 16 July 2019.

Veall, Michael R. and Klaus F. Zimmermann (1996), Pseudo-R2 Measures for Some Common Limited Dependent Variable Models, Journal of Economic Surveys, Vol. 10, No. 3, pp. 241-259.

Vrame, Anton C. (2006), An Overview of Orthodox Christian Religious Education, in: Marian de Souza, Gloria Durka, Kathleen Engebretson and Robert Jackson (eds.), International Handbook of the Religious, Moral and Spiritual Dimensions in Education, Part 1, Dordrecht: Springer, pp. 277-292.

Weir, Sharada (2011), Parental Attitudes and Demand for Schooling in Ethiopia, Journal of African Economies, Vol. 20, No. 1, pp. 90-110.

Weiss, Heather B., Ellen Mayer, Holly Kreider, Margaret Vaughan, Eric Dearing, Rebecca Hencke and Kristina Pinto (2003), Making It Work: Low-Income Working Mothers' Involvement in their Children's Education, American Educational Research Journal, Vol. 40, No. 4, pp. 879-901.

World Bank (1993), The East Asian Miracle: Economic Growth and Public Policy, Oxford: Oxford University Press.

Yang, Huanyin (1993), Confucius (K'ung Tzu) (551-479 вс), Prospects: Quarterly Review of Comparative Education, Vol. 23, Nos. 1-2, pp. 211-219.

Zeldin, Michael (2011), Preface, in: Helena Miller, Lisa D. Grant and Alex Pomson (eds.), International Handbook of Jewish Education, Part 1, Dordrecht: Springer, pp. v-viii. 


\section{Appendix}

TABLE A1 Respondents below the age of 25 excluded

\begin{tabular}{|c|c|c|c|c|}
\hline & $\begin{array}{l}(1) \\
\text { Inadequate } \\
\text { education } \\
\text { most serious } \\
\text { problem of } \\
\text { the world }\end{array}$ & $\begin{array}{l}(2) \\
\text { Inadequate } \\
\text { education } \\
\text { most serious } \\
\text { problem for } \\
\text { their own } \\
\text { country }\end{array}$ & $\begin{array}{l}(3) \\
\text { Worried about } \\
\text { not being able } \\
\text { to give their } \\
\text { children a } \\
\text { good } \\
\text { education }\end{array}$ & $\begin{array}{l}\text { (4) } \\
\text { University } \\
\text { more } \\
\text { important } \\
\text { for a boy } \\
\text { than for a } \\
\text { girl }\end{array}$ \\
\hline \multicolumn{5}{|l|}{ Panel A. Main models } \\
\hline Elementary education & $\begin{array}{c}0.010 \\
(0.008)\end{array}$ & $\begin{array}{c}0.020^{*} \\
(0.011)\end{array}$ & $\begin{array}{c}0.022 \\
(0.024)\end{array}$ & $\begin{array}{c}-0.017 \\
(0.012)\end{array}$ \\
\hline Middle education & $\begin{array}{l}0.026^{* * *} \\
(0.007)\end{array}$ & $\begin{array}{l}0.034^{* *} \\
(0.014)\end{array}$ & $\begin{array}{c}0.019 \\
(0.016)\end{array}$ & $\begin{array}{l}-0.063^{* * *} \\
(0.009)\end{array}$ \\
\hline Higher education & $\begin{array}{l}0.050^{* * *} \\
(0.009)\end{array}$ & $\begin{array}{l}0.05^{* * *} \\
(0.015)\end{array}$ & $\begin{array}{c}-0.002 \\
(0.018)\end{array}$ & $\begin{array}{l}-0.111^{* * *} \\
(0.013)\end{array}$ \\
\hline Other explanatory variables & Yes & Yes & Yes & Yes \\
\hline Country dummies & Yes & Yes & Yes & Yes \\
\hline Year dummies & Yes & No & No & Yes \\
\hline Number of observations & 47,666 & 16,690 & 30,279 & 48,815 \\
\hline Number of countries & 55 & 26 & 39 & 55 \\
\hline \multicolumn{5}{|l|}{ Pseudo $R^{2}$} \\
\hline McFadden & 0.07 & 0.04 & 0.19 & 0.12 \\
\hline McKelvey and Zavoina & 0.13 & 0.10 & 0.33 & 0.25 \\
\hline \multicolumn{5}{|l|}{ Panel B. GDP per capita added } \\
\hline Elementary education & $\begin{array}{c}0.012 \\
(0.008)\end{array}$ & $\begin{array}{c}0.019 \\
(0.011)\end{array}$ & $\begin{array}{c}0.026 \\
(0.023)\end{array}$ & $\begin{array}{c}-0.016 \\
(0.013)\end{array}$ \\
\hline Middle education & $\begin{array}{l}0.027^{* * *} \\
(0.007)\end{array}$ & $\begin{array}{l}0.035^{* *} \\
(0.015)\end{array}$ & $\begin{array}{c}0.022 \\
(0.018)\end{array}$ & $\begin{array}{l}-0.064^{* * *} \\
(0.010)\end{array}$ \\
\hline Higher education & $\begin{array}{l}0.050^{* * *} \\
(0.010)\end{array}$ & $\begin{array}{l}0.052^{* * *} \\
(0.016)\end{array}$ & $\begin{array}{l}-0.004 \\
(0.020)\end{array}$ & $\begin{array}{l}-0.113^{* * *} \\
(0.014)\end{array}$ \\
\hline Other explanatory variables & Yes & Yes & Yes & Yes \\
\hline Country dummies & Yes & Yes & Yes & Yes \\
\hline Year dummies & Yes & No & No & Yes \\
\hline Number of observations & 44,384 & 14,999 & 27,755 & 44,565 \\
\hline Number of countries & $5^{\circ}$ & 24 & 35 & $5^{\circ}$ \\
\hline
\end{tabular}




\begin{tabular}{lllll}
\hline & $(1)$ & $(2)$ & $(3)$ & $(4)$ \\
$\begin{array}{l}\text { Inadequate } \\
\text { education } \\
\text { most serious } \\
\text { problem of } \\
\text { the world }\end{array}$ & $\begin{array}{l}\text { Inadequate } \\
\text { education } \\
\text { most serious } \\
\text { problem for } \\
\text { their own } \\
\text { country }\end{array}$ & $\begin{array}{l}\text { Worried about } \\
\text { not being able } \\
\text { to give their } \\
\text { children a } \\
\text { good } \\
\text { education }\end{array}$ & $\begin{array}{l}\text { Unore } \\
\text { important } \\
\text { for a boy } \\
\text { than for a } \\
\text { girl }\end{array}$ \\
& & & & \\
Pseudo $R^{2}$ & & 0.05 & 0.20 & 0.12 \\
McFadden & 0.07 & 0.10 & 0.35 & 0.24 \\
McKelvey and Zavoina & 0.13 & & & \\
\hline
\end{tabular}

Note: Conditional marginal effects of probit regressions, calculated at the means. Robust standard errors, adjusted for clustering at the country level, are reported in parentheses. In addition to the explanatory variables mentioned above, the regressions of panel A (panel B) additionally use the same explanatory variables as the regressions of Table 2 (Table 3); for brevity, the estimates for these variables are omitted. The data are from World Values Survey waves 5 (2005-09) and 6 (2010-14), except regressions 2, which are based on data from wave 5 only, and regressions 3, which are based on data from wave 6 only (Inglehart et al. 2015). Data on 'GDP per capita' are from Feenstra et al. $(2019) .{ }^{* * *}\left({ }^{* *} /{ }^{*}\right)$ denotes statistically significant at the $1 \%(5 \% / 10 \%)$ level.

\section{List of Countries}

Algeria, Andorra, Armenia, Australia, Azerbaijan, Belarus, Brazil, Bulgaria, Burkina Faso, Canada, Chile, Colombia, Cyprus, Ecuador, Estonia, Ethiopia, Germany, Ghana, Hungary, India, Indonesia, Iraq, Italy, Kazakhstan, Kyrgyzstan, Lebanon, Libya, Malaysia, Mali, Mexico, Moldova, Morocco, Netherlands, New Zealand, Nigeria, Peru, Philippines, Poland, Romania, Russia, Rwanda, Serbia and Montenegro, South Africa, Sweden, Taiwan, Thailand, Trinidad and Tobago, Tunisia, Ukraine, Uruguay, Uzbekistan, Vietnam, Yemen, Zambia, Zimbabwe. 